\title{
Building Economic Opportunity on Indian Reservations
}

\author{
Deirdre McGlonet
}

Deirdre MCGlone is studying state and local government management at The George Washington University. She received her Bachelor of Arts degree in political science from the University of Illinois at Urbana-Champaign and is working as a program analyst for the Food and Drug Administration.

Iast December, I visited a small Chippewa reservation in the upper peninsula of Michigan. After reading many arguments for and against Indian gaming, I wanted a first-hand look at reservation life and the effects of gaming. I expected to find a miniature version of Atlantic City but was surprised instead to encounter a miniature version of the public housing development in my hometown. The reservation covered perhaps a square mile and was scattered with approximately 30 tiny, single-family homes, all in need of insulation and repair.

While I was prepared for the poor conditions of the reservation, I was surprised by the casino. It was an aluminum shed - no different than a modern barn - with blinking lights over the door. I could hardly believe that this unadorned, entirely non-cosmopolitan building had caused so much controversy, prompting federal legislation and causing traditional gambling entrepreneurs to fear for their livelihood. Inside this barn were slot and video poker machines, blackjack tables, cocktail waitresses, and most importantly, gamblers. All were busy.

Gambling has changed the face of Indian reservations. This billion dollar industry is bringing in revenue to some of the neediest people in the United States. Still, debate continues over whether some better alternative exists to Indians relying on such a controversial industry. This article will discuss the many facets of Indian gaming and attempt to justify the continuation of gaming in light of three alternative approaches for developing reservation economies. Finally, several incremental changes will be recommended in order to remedy some of the reservation problems that gaming does not address.

\section{History}

Early American Indians never planned on turning their lands into gambling resorts. Rather, tribes stumbled onto gambling out of necessity and opportunity, since reserva- tions were not created with business opportunity and Indian well-being in mind. During the American expansionist period, tribes were relegated to those lands no one else wanted. When those same lands became valuable, either to settlers seeking homesteads or to prospectors extracting mineral deposits, many tribes were again relocated against their wills. Tribal economics and self-sufficiency were not principal concerns of the federal government at that time. The reservations were merely meant to serve as small tracts of land Indians could call their own.

Today, Indian reservations are some of the poorest and most desolate places in the country. Most are situated in remote locations, far from populated areas and major transportation routes. Generally, these lands are also illsuited for industrial development. Consequently, unemployment rates can average as high as 75 percent on the larger reservations.' Social problems such as alcoholism, drug abuse, domestic violence and lack of education also permeate Indian communities. The very few Indians who leave reservations to pursue higher education and careers seldom return; leaving tribes with too few well-trained leaders and role models.

The past 15 years have brought some dramatic changes to tribes. Even though states tried to close down Indian casinos and Bingo halls, such as one Seminole Tribe's Bingo operation in Florida, the courts have consistently upheld a tribal exemption from state regulation of gaming. ${ }^{2}$ During the 1980 s, a succession of cases, combined with the Indian desire for self-reliance, encouraged tribes to pursue the creation, expansion and improvement of Indian gaming facilities. ${ }^{3}$ Today, this growth continues with tribes such as the Yankton Sioux of South Dakota, whose gaming business surpassed the capabilities of the tribe's contracted management firm within one month of opening the casino. ${ }^{4}$ 
Opposition to this booming industry grew quickly. The main source of objection came from states surrounding the reservations that attempted to have Indian Bingo halls and casinos shut down. However, the courts were usually inclined to protect the semi-sovereignty of tribes within their own lands.

Years of court cases, state opposition to gaming, and the potential for involvement by organized crime prompted Congress to enact the Indian Gaming Regulatory Act (IGRA) in 1988.5 This Act addresses two concerns. First, the Act separates gaming into three categories and specifies the regulatory control over each class. Second, the IGRA creates the National Indian Gaming Commission to regulate portions of gaming, to approve management contracts, and to conduct background investigations on those Indians and non-Indians working in this new industry.

Under this law, Class I games, consisting of traditional tribal games, are to be regulated solely by the tribes. The National Indian Gaming Commission is charged with the regulation of Class II games, namely Bingo. Class III games, including video poker, slot machines, and blackjack, are to be covered under Tribal-State compacts. According to the IGRA, a tribe can only offer the level of gaming legal in that state, in accordance with a TribalState Compact. ${ }^{6}$ However, if a state allows casino-type games for charity events or special occasions, the state cannot próhibit Indians from offering those same games on reservations.' Any regulation other than which games are allowed is left to the individual Tribal-State Compact. ${ }^{8}$

Subsequently, these compacts have become one of the key issues in Indian gaming. The IGRA's only requirement in the development of these compacts is that a state negotiate in good faith with tribes seeking to open casinos. Not surprisingly, states and tribes differ significantly in their opinions of what constitutes good faith negotiations. When a state and tribe fail to reach an agreement within 180 days of the tribe's request for negotiations, the tribe may file a complaint in Federal District Court. The court then gives the state and tribe 60 additional days in which to reach a compromise before sending both sides' original proposals to a mediator. This mediator then selects one of the two proposals. The state and tribe are then allowed another 60 days to ratify the compact. Failure to ratify the mediator's choice sends the issue directly to the Secretary of the Interior, who makes the final, binding decision.?

At least 20 states have become involved in gaming-related litigation; ${ }^{10}$ however, the decisions in these cases have generally favored the Indians. Additionally, Interior Secretary Bruce Babbitt, who has determined a number of major compacts, has been consistent in protecting Indian interests." ${ }^{11}$ Thus, states may actually lose more than they gain by refusing to negotiate with tribes. While reservation casinos are not subject to state sales and property taxes, states have other avenues available to make Indian gaming profitable to both the tribe and the state. The Mashantucket Pequot tribe will pay the state of Connecticut at least $\$ 100$ million this year in order to remain the only casino with slot machines in the state, essentially eliminating all in-state competition. ${ }^{12}$ This agreement benefits the Pequots and provides a significant revenue boost to the state.

\section{"In 1991 alone, Indian gaming boasted a growth rate of 105 percent, while the industry as a whole experienced growth at under one percent."}

States are not the only opponents of Indian gaming; the casino industry has also been polarized by Indian gaming. The industry's suppliers of slot machines, video poker machines and casino management services are finding this new market quite profitable. On the other hand, when the "nation's largest gaming facility," the Foxwoods High Stakes Bingo and Casino Resort in Connecticut, ${ }^{13}$ was opened by the Mashantucket Pequot tribe last year, the big casinos in Las Vegas, Reno, Nevada, and Atlantic City, New Jersey, watched closely. These rivals have reason for concern. In 1991 alone, Indian gaming boasted a growth rate of 105 percent, while the industry as a whole experienced growth at under one percent." In fact, non-Indian casinos are beginning to feel threatened by the Indians. Donald Trump, creator of the nation's largest casino in operation, the Taj Mahal in Atlantic City, has repeatedly attacked the constiutionality of the IGRA, alleging that the Act gives Indians an unfair advantage in the gambling industry.15

All of this controversy over gaming has raised the possibility that Congress may be forced to establish clearer rules for tribal casinos. Current law does not address all of the important issues surrounding gaming and states, and non-Indian casino operators are pressuring Congress to take another look at the IGRA. General Indian sentiment is that the present Congress is not as sympathetic to the tribes as was the 1988 Congress. ${ }^{16}$ Any revisions in 
the IGRA could mean big changes, especially in the tribes' positions relative to the states.

On the other hand, Indian tribes are happy with the outcomes the IGRA has produced. In less than a decade, Indian gaming has become a $\$ 6$ billion industry ${ }^{17}$ and is the only industry to give many tribes hope for the future. The revenue from Bingo halls and casinos has enabled tribes to provide much-needed jobs, social services and stability to tribal members. Additionally, tribes now have funds to invest in their futures. Higher education scholarships and infrastructure development are two of the ways Indians are trying to improve their communities with gaming revenues.

\section{Alternatives}

While gaming has yielded great rewards for Indian tribes, debate continues over creating long-term economic development on reservations through gaming. A number of other options have been, and continue to be, considered, including private development of reservations, the replacement of the Bureau of Indian Affairs with direct grants to tribes, and micro-enterprise development.

The three main stakeholders in Indian policy - the Indians, the federal government and the states - have strong feelings about gaming and the alternative methods of economic development. Obviously, the Indians have the most to gain or lose in this policy decision. They want a better standard of living, more jobs, and a chance to become self-sufficient. Unfortunately, the dire financial condition of most tribes pressures them to concentrate on short-term solutions. Striking a balance between providing immediate relief and investing in the future is a challenge for tribal leaders.

Further, Indian culture is especially protective of the environment and does not usually support economic development that results in significant pollution. Also, Indians have a historic distrust of whites - including the federal government - and have not forgotten those who destroyed their way of life. Since 1837, the federal government has held Indian monies in trust through the Bureau of Indian Affairs. -Unfortunately, gross mismanagement of these trust funds has meant losses estimated anywhere from $\$ 17$ million $^{18}$ to $\$ 65$ million $^{19}$ per year from these trusts.

This scandal has not only shaken Indian confidence in the BLA but has also created concem in Congress over the Bureau's administrative ability. While the federal government has an interest in promoting Indian self-reliance, Congress is reluctant to place any greater responsibility in the BIA. In fact, the investigative subcommittee of the Senate Select
Committee on Indian Affairs recommended that the current system of BIA-run programs be replaced with direct grants to tribes. ${ }^{20}$ Indians likewise favor reliance on Indian resourcefulness instead of ineffective BIA programs.

Along with an interest in increasing tribal economic independence, the federal government plays the role of partial protector of Indian tribes. Reports of fraud and abuse of tribes by private businesses have prompted an increased federal effort to monitor Indian business dealings more closely. Thus, Indians are also subject to regulation of both their public and private business and financial dealings.

The third group of stakeholders in Indian policy are the states where the reservations are located. To their dismay, states have little control over Indian activities on reservations. For the most part, states do not take an active position on general tribal policies. However, when certain issues are raised, such as taxing authority, environmental damage and gaming regulation, the states make their positions known.

\section{Private Development}

Until recently, the private development alternative to gaming has been limited mainly to the extraction of natural resources from reservations. For those tribes with oil-rich land, for example, private interest is easy to find, Unfortunately, only a few of the tribes have enough resources to support the desired standard of living. For those tribes without such opportunities, luring private business to the reservations is a difficult task. The lack of infrastructure, skilled labor and access to major transportation routes undermine the ability of reservations to compete with more modern, technologically-advanced communities. Those businesses that do find reservations attractive are not always suited to Indian culture.

Recently, companies specializing in the disposal of hospital, domestic, and toxic wastes have indicated an interest in pursuing disposal sites on tribal lands. ${ }^{21}$ These companies may simply want to take advantage of the freedom from federal environmental regulation held by Indian tribes. ${ }^{22}$ Remote reservations are also less vulnerable to the "not in my back yard" (or NIMBY) protests that so often surround other prospective sites.

Another major problem for non-Indian development on reservations is taxing authority. Although tribes are not subject to state taxes, laws determining the ability of states to tax non-Indian businesses operating on reservations are not clear. ${ }^{23}$ Consequently, a non-Indian business operating on tribal property risks being taxed by both 
the tribe and the state, in addition to the federal government. Courts have split, favoring both sides in this matter and creating uncertainty about whether a given business will be subject to state taxes above and beyond Indian taxes. ${ }^{24}$ Tribes and states could resolve this problem by negotiating tax revenue sharing plans, thus eliminating the need for costly litigation and encouraging private development of reservations. However, states and tribes still are willing to risk revenue in order to retain full taxing authority and to deter business development rather than negotiate with one another. ${ }^{2 s}$

Tribes do not have much to offer private businesses. With time and money, workers can be trained and infrastructure improved, but the poor location of reservations cannot be changed. However, with many non-Indian communities offering so much more to businesses, Indian reservations have little chance of attracting the businesses that can sustain trade and help a community to prosper.

\section{Replace BIA Programs with Direct Grants to Tribes}

Replacing BIA programs with direct grants to tribes is a popular alternative with Indians. The federal government spends roughly $\$ 3.3$ billion on Indian programs annual$1 y^{26}$ for the two million Native Americans in the country ${ }^{27}$ and gets dismal results; thus, replacing government programs with tribal initiatives may find support in Congress. However, Wilma Mankiller, Cherokee Nation Chief, who supports this idea, has stated a common sentiment: given the entrenched nature of the bureaucracy, dismantling a federal agency is probably not a realistic idea. ${ }^{23}$

If direct grants to tribes were initiated, protecting the integrity of the program is paramount. Tribes may be asked to restructure their governments to prevent domination by a particular individual, and other measures could be put in place to ensure that the grants were not embezzled or misappropriated.99

The disadvantages of increasing the number of direct grants to tribes are speculative. Fistorically, when tribes have been awarded large sums of money (usually by the courts) the result is an economic boost for nearby, non-Indian economies. Few reservations are equipped with even the most basic services and many purchase necessicies from non-Indian merchants. If grant money is funneled through tribes to individuals, the money could quickly leave the reservation. A dramatic example of this occurrence is the Pine Ridge reservation, where 91 percent of the $\$ 82$ million received by the tribe and individuals each year is spent on non-Indian business. ${ }^{30}$
The lack of strong, financially knowledgeable leadership on reservations may also limit the effectiveness of grants to solve economic problems. If the BIA could be dismantled, and if the tribal leaders could ensure sound, effective use of these grants, this alternative might have more support. Yet the extremely low feasibility of dismantling the BIA greatly undermines this option. Congress cannot be expected to fund both the BIA and a dramatically increased tribal grant program. Therefore, this alternative is not politically feasible

\section{Micro-Enterprise Development}

Micro-enterprise development, a relatively new approach to economic development, promotes the creation of small businesses on reservations on a case-by-case basis. The proposed programs under this approach include modest loans and entrepreneurial training for individuals or small groups seeking to start their own businesses. While the Small Business Administration claims that three-fifths of all small businesses fail in the first six years, ${ }^{31}$ supporters of this idea contend that those that fail probably did not have the support or training provided under micro-enterprise programs.

\begin{tabular}{l}
\hline "The federal government spends \\
rougbly $\$ 3.3$ billion on Indian \\
programs annually for the two \\
million Native Americans in the \\
country and gets dismal results...."
\end{tabular}

The need for basic services on reservations creates a market ripe for development by Indians. While this market is not abundant, Indian gas stations and convenience stores have enjoyed moderate success in the past several years. The popularity of Indian arts and crafts presents another viable business opportunity for Indians. For example, Robert Redford's Sundance Catalog and Ralph Iauren's Polo Stores both buy Navajo jewelry from a small, non-Indian, jewelry wholesale company. ${ }^{32}$ With an understanding of management techniques, this same business could be run by Indians, increasing the overall share in profits from Indian products.

The advantages of micro-enterprise development are increased self-sufficiency and development of individual talents, skills, and motivation. Unfortunately, providing business training, financial consultation, and small loans 
on an individual basis is an expensive undertaking. Further, while several non-Indian groups have had some initial success with micro-enterprise programs, these efforts are relatively new and long-term effects are uncertain. A non-Indian example of a micro-enterprise program is the Women's Self-Employment Project (WSEP) in Chicago, which makes small loans, usually in hundreds of dollars, to low-income women who want to start new businesses. ${ }^{33}$ The success of these small businesses is tempered by the fact that the WSEP loses money on these loans, (a program of smaller loans costs more to administer than do larger loans)..$^{34}$ Federal or tribal governments attempting micro-enterprise projects would probably have to absorb these costs. Micro-enterprise development is an expensive undertaking, with uncertain long-term benefits, and is the unlikely choice of either the federal or tribal governments.

\section{Gaming}

In relation to the other policy options under consideration, gaming has one big advantage. While the others are more experimental, gaming has already proved itself, at least in the short run. However, gaming raises serious doubts about the long-term stability of reservations' economies. Most notably, gaming has taken tribes from no-industry communities to one-industry communities. Although this is progress, many tribes are now entirely dependent on one business, the casino. Should the market for casinos and Bingo halls become saturated, or should gaming lose its current popularity, tribes have no alternative.

The suitability of gaming to a low-skilled work force is a double-edged sword, since gaming does not improve workers' skills. Consequently, if gaming ever fails to sustain Indians, tribes could end up in the same distressed economic condition that existed before gaming. Although gaming is lucrative, it fails to keep money within reservation economies. Indians still spend an average of at least 50 percent of their household income at businesses off reservations. ${ }^{35}$ This diversion of revenue decreases the financial stability of tribes, and, coupled with political pressures, makes long-range financial planning even more difficult for tribal leaders. Chiefs and council members are struggling to make tough decisions about the distribution of gaming profits; the money could be distributed directly to tribal members (although this money may immediately leave the tribe's economy), or invested in long-term projects, which are not always popular among those constituents still living in poverty.

\section{Recommendations}

Although gaming falls short in several areas of economic development for reservations, opportunities exist for tribes to ensure long-range economic security. Tribes should use gaming as a tool to improve the quality of the Indian work force. Even though the industry provides many low-skill or no-skill positions, management is an integral part of the gaming industry. Lack of casino experience, and business experience in general, has led many tribes to contract out the management of their casinos to the approximately 150 non-Indian management and investment groups working with Indian gaming projects. ${ }^{36}$ Tribes want to guarantee that their interests and investments are protected by qualified individuals, yet tribal members will not develop this expertise unless they are allowed to gain firsthand experience in casino operation. Over time, the numbers of Indians actually managing the tribal casinos will surely increase, but concentrated efforts by tribes to speed up the education and training process would help to put more Indian casinos under Indian management, making tribes even more self-reliant.

\begin{tabular}{c}
\hline \hline "Gaming has taken tribes from \\
no-industry communities to \\
one-industry communities. \\
Altbougb tbis is progress, many \\
tribes are now entirely dependent \\
on one business, tbe casino." \\
\hline
\end{tabular}

Another step tribes should take to increase economic growth is to develop the secondary businesses associated with casinos. Restaurants, hotels, and general stores are all supported by the gaming industry. The number of articles devoted to Indian gaming in restaurant and hotel trade magazines indicates that the tourism industry foresees a profitable market for these services near Indian casinos. Hotels and motels near Indian gaming operations have even entered into cooperative marketing agreements and offered package deals with Indian casinos to promote business. ${ }^{37}$ Casinos draw patrons who need food and shelter, even if only for one night. Tribes should take advantage of this opportunity and provide meals and lodging on reservations instead of forcing patrons to seek these necessities at nearby, nonIndian communities. 
Investing in small businesses requires coordination and commitment from tribes. The fledgling restaurants and hotels require venture capital, trained managers, and community patronage during the early years. Uncharacteristic of other micro-enterprise programs, these businesses already have a high demand for their service, lessening the risks associated with new businesses. Tribes whose casinos are drawing steady revenues should encourage their members to undertake such ventures. Admittedly, this kind of development relies entirely on the gaming industry. However, should the industry ever falter, tribes will be left with a more experienced, educated, and marketable work force, ready to adapt to new economic opportunities.

For those tribes not yet ready to pursue Indian-owned and operated businesses, such as restaurants and hotels, encouraging private development of these industries on tribal land is a better alternative than continuing to allow non-Indian communities to reap all of the secondary benefits of gaming. If tribes do not enter this secondary market, they should at least attempt to maximize profits by entering into partnerships with private developers who appreciate the importance of keeping patrons, and their expenditures, on the reservations. The revenue generated from these ventures should then be invested back into the reservation through infrastructure improvement, education, and job training.

Finally, tribes have enough leverage to resolve some of the tribal-state tax conflicts that deter businesses from developing on reservations. Tribes must recognize this conflict as a serious barrier to development and focus their efforts on resolving these problems ahead of time to make reservations more attractive to the business community.

Gaming is an industry with limitations. Casinos and Bingo halls cannot, nor should they be expected to, solve Indian problems, yet gaming creates a comerstone upon which tribes can build their economies. The revenue generated by gaming allows tribes to strengthen their funtres by providing investment in infrastructure, education, and solutions for the variety of social problems plaguing reservations. No other alternative, by itself, guarantees Indians the ability to turn their initiative, persistence, and desire for self-reliance into reality. Decades into the future, gaming may not be the business of choice for reservations; however, at the moment, casinos are Indians' best bet. $\star$

\section{Notes}

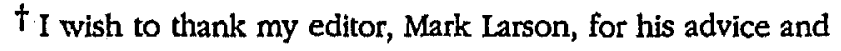
suggestions. I would also like to thank Professor Bayard Catron for his invaluable assistance and Kathleen Donahue for her diligent work on this article.

1 Cohen, Daniel, "Tribal Enterprise," Atlantic, v. 264, October 1989, p. 34.

2 Oleck, Joan, "Tribal Warfare," Restaurant Business, June 10, 1993, p. 58.

3 Ibid.

4 Ibid.

5 United States, 100th Congress Second Session, "Indian Gaming Regulatory Act," Public Law 100-497, October 17, 1988.

${ }^{6}$ Monteau, Harold A., "Summary of Tribal-State Gambling Compacts For Class III Gaming," prepared for the National Indian Policy Center, Washington, D.C., pp. 25-26.

7 Oleck, p. 62.

8 Monteau, pp.25-27.

9 Ibid., p. $26-27$.

10 Ibid., p. 31.

11 Oleck, p. 58.

12 Yoshihashi, Pauline, "As Indian Casinos Spread, Politicians and Rivals Maneuver to Fight the Trend," Wall Street Journal, May 4, 1993, B1,B6.

13 Oleck, p. 56.

14 Robinson, Robert, "The Economic Impact of Indian Reservation-based Gaming Activities," prepared for the National Indian Policy Center, p. 13.

15 Oleck, p. 58.

16 Ibid., p. 62.

17 Ibid.

18 McAllister, Bill, "The Tribes' Lost Trust; 152 Years Ago, Indians Put Their Funds In Government Hands, "Washington Post, October 27, 1989, A:17.

19 Report Says," Washington Post, April 4, 1992, A:3.

20 McAllister, Bill, and John Lancaster, "Senate Panel Wants Overhaul of Federal Indian Programs," Washington Post, November 18,1989 , A:1. 
21 Tomsho, Robert, "Dumping Grounds: Indian Tribes contend with some of the worst of America's pollution. Reservations now look good to promoters of facilities for toxic waste disposal. Spirit of the river weakens.," Wall Street Joumal, November 29, 1990, A:1.

22 Ibid.

23 Endreson, Douglas B.L., "Resolving Tribal-State Tax Conflicts," prepared for the National Indian Policy Center, June 21, 1991, pp. 2-4.

24 Ibid.

25 Endreson, pp. 8-10.

26 McAllister and Lancaster, p. A:1.

27 Schwartz, Maralee, "Changing the Approach to Indians' Problems; Miller Native American Viewpoint Important," Washington Post, April 17, 1991, A:19.

28 McAllister and Lancaster, A:1.
29 Ibid.

30 Cohen, p. 42.

31 Robichaux, Mark, "Enterprise: Entrepreneur Training Tries to Break the Welfare Chain," Wall Street Journal, August 7, 1989.

32 Atchison, Sandra, "Turquoise, Soda Pop, and Terminator 2," Business Week, November 2, 1992, p. 22H.

33 Wessel, David, "Doing Business in the Inner City - Small Victories: Two Unusual Lenders Show How 'Bad Risks' Can Be Good Business; Chicago 'Borrowing Circle' Uses Peer Pressure To Get Enviable Payback Rate, Bank Uses Personal Touch," Wall Street Joumal, June 23, 1992, A:1.

34 Ibtd.

35 Robinson, p. 15.

36 oleck, p. 62.

37 Shaw, Russell, "Casino Co-op Marketing Helps Hotels Hit Jackpot," Hotel \& Motel Managemenit, February 22, 1993.

\section{Bibliography}

Atchison, Sandra, "Turquoise, Soda Pop, and Terminator 2 ," Business Week, November 2, 1992, p. 22D-H.

Cohen, Daniel, "Tribal Enterprise," Atlantic, v. 264, October, 19889, pp. 32-48.

Endreson, Douglas B.L., "Resolving Tribal-State Tax Conflicts," prepared for the National Indian Policy Center, June 21, 1991.

Mcallister, Bill, "The Tribes' Lost Trust; 152 Years Ago, Indians Put Their Funds in Government Hands," Washington Post, October 27, 1989, A:17.

"Investments Cost BIA \$65 Million in One Year," Wasbington Post, April 4, 1992, A:3.

McAllister, Bill and John Lancaster, "Senate Panel Wants Overhaul of Federal Indian Programs," Wasbington Post, November 18, 1989, A:1.

Monteau, Harold A., "Summary of Tribal-State Gambling Compacts For Class III Gaming," prepared for the National Indian Policy Center, Washington, D.C.

Oleck, Joan, "Tribal Warfare," Restaurant Business, June 10, 1993, pp. 56-66.
Robichaux, Mark, "Enterprise: Entrepreneur Training Tries to Break the Welfare Chain," Wall Street Journal, August 7, 1989.

Robinson, Robert, "The Economic Impact of Indian ReservationBased Gaming Activities," prepared for the National Indian Policy Center.

Schwartz, Maralee, "Changing the Approach to Indians' Problems; Miller Native American Viewpoint Important," Wasbington Post, April 17, 1991, A:19.

Shaw, Russell, "Casino Co-op Marketing Helps Hotels Hit Jackpot," Hotel \& Motel Management, February 22, 1993.

United States, 100th Congress Second Session, "Indian Gaming Regulatory Act," Public Law 100-497, October 17, 1988.

Wessel, David, "Doing Business in the Inner City - Small Victories: Two Unusual Lenders Show How 'Bad Risks' Can Be Good Business; Chicago 'Borrowing Circle' Uses Peer Pressure to Get Enviable Payback Rate, Bank Uses Personal Touch," Wall Street Journal, June 23, 1992, A:1.

Yoshihashi, Pauline, "As Indian Casinos Spread, Politicians and Rivals Maneuver to Fight the Trend," Wall Street Joumal, May 4, 1993, B1, B6. * 